\title{
Pengaruh Lama Perendaman dan Suhu Air Terhadap Pemecahan Dormansi Benih Sengon (Paraseriathes falcataria (L.) Nielsen)
}

\author{
Effect of Seed Soaking and Water Temperature \\ on Dormancy Break of Sengon Seed \\ (Paraseriathes falcataria (L.) Nielsen) \\ Nasrul dan Nelly Fridayanti \\ Program Studi Agroekoteknologi, Fakultas Pertanian, Universitas Malikussaleh \\ Kampus Cot Teungku Nie, Reuleut, Muara Batu Aceh Utara 24355, Indonesia \\ Email: agrium.fpunimal@yahoo.co.id
}

Diterima 1 Agustus 2014; Dipublikasi 1 September 2014

\begin{abstract}
Abstrak
Tujuan penelitian adalah untuk mempelajari pengaruh perendaman benih dan suhu air terhadap pemecahan dormansi benih sengon. Setiap percobaan disusun dalam rancangan acak kelompok dengan dua faktor yaitu perendaman dan suhu air. Hasil penelitian menunjukkan bahwa perendaman berpengaruh tidak nyata pada viabilitas benih termasuk persen perkecambahan, indeks vigor, potensi tumbuh maksimum dan keserempakan tumbuh. Suhu air berpengaruh nyata pada potensi tumbuh maksimum, persen perkecambahan, keserempakan tumbuh namun tidak berpengaruh pada kecepatan tumbuh dan indesks vigor.
\end{abstract}

Kata kunci: perendaman, suhu air, dormansi, viabilitas benih

\begin{abstract}
This research aims to study effect soaking seed and water temperature of break dormancy germination sengon seed. Each experiment was arranged in a randomized block design with two factor that was soaking and water temparatuer. The results showed that the soaking effect was not significant on the seed viability including germination percentage, vigor index, maximum growth potential and the uniformity growth. The water temperature effect significantly on maximum growth potential, germination percentage, the uniformity growth but not significant on growth rapid and vigor index.
\end{abstract}

Keywords: soaking, water temperature, dormancy, seed viability.

\section{Pendahuluan}

Tanaman sengon memiliki nilai ekonomis yang tinggi dan prospektif untuk dikembangkan. Tanaman sengon memiliki manfaat yang cukup besar dalam upaya merehabilitasi tanah kritis dan saat ini permintaan kayu sengon yang terus meningkat. Salah satu usaha pemerintah khususnya (Departemen Kehutanan) melalui Dinas Pertanian Tanaman Pangan, Kehutanan dan Perkebunan telah lama mencanangkan program sengonisasi yang tiap tahunnya di laksanakan di Kabupaten Probolinggo (Razi, 2012).

Berbagai macam teknik pembibitan secara tradisional telah dilakukan berdasarkan pengalaman yang mereka miliki. Secara garis besar tidak menemukan kendala yang berarti dalam melakukan pembibitan. Tetapi seiring dengan laju perkembangan budidaya sengon yang semakin tinggi sehingga membutuhkan bibit yang lebih banyak. Maka diperlukan terobosanterobosan baru untuk meningkatkan kapasitas teknik pembibitannya sehingga terus mengalami peningkatan (Sudomo, 2011). Benih dikatakan dorman apabila benih tersebut sebenarnya hidup tetapi tidak berkecambah walaupun diletakkan pada keadaan yang secara umum dianggap telah memenuhi persyaratan bagi suatu perkecambahan (Sutopo, 2004).

Dormansi pada benih dapat berlangsung selama beberapa hari, semusim, bahkan sampai beberapa tahun tergantung pada jenis tanaman dan tipe dari dormansinya. Pertumbuhan tidak akan terjadi selama benih belum melalui masa dormansi-nya, atau sebelum dikenakan suatu perlakuan khusus terhadap benih tersebut. Dormansi dapat dipandang sebagai salah satu 
keuntungan biologis dari benih dalam mengadaptasikan siklus pertumbuhan tana-man terhadap keadaan lingkungannya, baik musim maupun variasi-variasi yang kebetulan terjadi. Sehingga secara tidak langsung benih dapat menghindarkan dirinya dari kemusnahan alam (Sutopo, 2004).

Dormansi pada benih dapat disebabkan oleh keadaan fisik dari kulit biji, keadaan fisiologis dari embrio, atau kombinasi dari kedua keadaan tersebut. Sebagai contoh kulit biji yang impermeabel terhadap air dan gas sering dijumpai pada benih-benih Leguminosae. Faktor yang menyebabkan hilangnya dormansi pada benih sangat bervariasi tergantung pada jenis tanaman dan tentu saja tipe dormansinya, antara lain yaitu karena temperatur yang sangat rendah dimusim dingin, perubahan temperatur yang silih berganti, menipisnya kulit biji, hilangnya kemampuan untuk menghasilkan zat-zat penghambat perkecambahan, adanya kegiatan dari mikro-organisme. Pemecahan dormansi dan penciptaan lingkungan yang cocok sangat perlu untuk memulai proses perkecambahan beberapa spesies. Perlakuan tergantung pada tipe dormansi yang terlibat (dor-mansi fisik dan dormansi fisiologi atau dormansi ganda). Perlakuan mencakup skarifikasi, stratifikasi, membiarkan embrio dan berbagai kombinasi dari perlakuanperlakuan ini, dengan pengaturan ling-kungan yang cocok. Perkecambahan benih yang mengandung kulit biji yang tidak permeabel dapat dirangsang dengan skarifikasi-pengubahan kulit biji untuk membuatnya menjadi permeabel terhadap gas-gas dan air. Tindakan air panas 77 $100^{\circ} \mathrm{C}$ efektif untuk benih "honey locust". Beberapa benih dapat diskarifikasi dengan tindakan H2SO4 (Komalasari, 2011).

Benih sengon memiliki dormansi primer yaitu tiga lapis kulit dan dua lapis kulit terluarnya kutikula dan palisade kedap terhadap air dan udara yang melindungi benih dari desikasi dan sering kali menghambat perkecambahan benih sengon, sehingga pemecahan dormansi harus dilakukan (Zanzibar dan Herdiana, 2006).

Salah satu cara yang dapat dilakukan untuk memecahkan dormansi pada benih sengon adalah dengan cara merendam benih dalam air panas (Abimanyu, 2002). Pencelupan dengan air panas dapat mempercepat proses imbibisi (penyerapan air) karena suhu memegang peranan yang sangat penting dalam memberikan tekanan untuk masuknya air ke dalam biji. Penelitian Suharti (2007) juga menyebutkan dengan perendaman air suhu awal panas $\left(100^{\circ} \mathrm{C}\right)$ selama
4 - 8 jam pada sengon dapat menghasilkan daya kecambah 70 - $90 \%$, hasil tersebut lebih baik jika dibandingkan dengan perendaman dengan air dingin, atau air panas $\left(50^{\circ} \mathrm{C}\right)$ dan $\left(70^{\circ} \mathrm{C}\right)$. Peren-daman benih dengan air dingin hanya menghasilkan daya kecambah 55\% (Setiadi et al., 2005).

Penelitian ini bertujuan untuk mengetahui berapa besarnya pengaruh lama perendaman dan suhu air perendaman terhadap pemecahan dormansi benih sengon.

\section{Metode Penelitian}

Penelitian dilaksanakan di Laboratorium Agroekoteknologi Fakultas Pertanian Universitas Malikussaleh. Pelaksanaan penelitian dimulai pada bulan November 2013 sampai dengan bulan Januari 2014. Penelitian ini menggunakan rancangan acak lengkap (RAL) pola faktorial. Faktor pertama lama perendaman (L); L0: tanpa perendaman (kontrol), L1: Perendaman 2 jam, L2: Perendaman 4 jam, L3: Perendaman 6 jam, L4: Perendaman 8 jam dan L5: Perendaman 10 jam. Faktor kedua adalah suhu air (S); S0: tanpa perlakuan (kontrol), S1: Suhu $40^{\circ} \mathrm{C}, \mathrm{S} 2$ : Suhu $50^{\circ} \mathrm{C}$ dan S3: Suhu $60^{\circ} \mathrm{C}$. Parameter yang diamati meliputi:

\section{Potensi Tumbuh Maksimum (PTM)}

Potensi tumbuh maksimum yaitu kemampuan benih untuk tumbuh atau berkecambah dalam kondisi yang optimum. Pengamatan terhadap potensi tumbuh maksimum dilakukan pada hari terakhir pengamatan terhadap semua benih yang menunjuk-kan gejala tumbuh. Potensi tumbuh maksimum kecambah dihitung dengan rumus:

$$
\text { PTM }=\frac{\text { Jumlah benih tumbuh }}{\text { Jumlah benih ditanam }} \times 100 \%
$$

\section{Daya Berkecambah Benih (DB)}

Daya berkecambah memberikan informasi kepada pemakai benih akan kemampuan benih tumbuh normal. Pengamatan dilakukan pada hari ke 5 hitungan ke-I dan hari ke 9 hitungan ke-II setelah tanam terhadap semua kecambah normal dengan rumus:

$\mathrm{DB}=\frac{\text { Jumlah kecambah normal pada hitungan ke }- \text { I dan ke }- \text { II }}{\text { Jumlah benihyang di tanam }} \times 100 \%$ 
Keserempakan Tumbuh $\left(K_{S T}\right)$

Keserempakan tumbuh di ukur berdasarkan persentase kecambah normal di antara pengamatan pertama dan pengamatan ke dua (hari ke 7). Persentase keserempakan tumbuh dapat di hitung dengan rumus:

$\mathrm{K}_{\mathrm{ST}}=\frac{\text { Jumlah kecambah normal }}{\text { Jumlah benih yang di tanam }} \times 100 \%$

\section{Kecepatan Tumbuh Benih $\left(K_{C T}\right)$}

Kecepatan tumbuh (perkecambahan) benih dihitung berdasarkan total tambahan kecambah normal setiap hari. Pengamatan dilakukan mulai saat benih di tanam sampai dengan hari terakhir pengamatan. Rumus yang digunakan adalah sebagai berikut:

$$
\mathrm{K}_{\mathrm{CT}}=\frac{\mathrm{N}_{1}}{\mathrm{D}_{1}}+\frac{\mathrm{N}_{2}}{\mathrm{D}_{2}}+\ldots .+\frac{\mathrm{N}_{\mathrm{n}}}{\mathrm{D}_{\mathrm{n}}}
$$

Keterangan :

$\mathrm{N}_{1}, \mathrm{~N}_{2}, \ldots . . \mathrm{N}_{\mathrm{n}}=$ Kecambah Normal $1,2, \ldots . ., \mathrm{n}$ hari setelah tanam; $D_{1}, D_{2}, \ldots . . D_{n}=$ Hari pengamatan

\section{Indeks Vigor (IV)}

Indeks vigor dihitung berdasarkan jumlah kecambah normal pada hitungan pertama (hari ke 5) setelah tanam dan dihitung dengan rumus:

IV $=\frac{\text { Jumlah kecambah normal pada hitungan ke }-\mathrm{I}}{\text { Jumlah benihyang di tanam }} \times 100 \%$

\section{Hasil dan Pembahasan}

Berdasarkan hasil analisis ragam perlakuan lama perendaman dan suhu air dapat dilihat pada rekapan pada Tabel 2. Rekapitulasi sidik ragam pada Tabel 2 menunjukkan bahwa perlakuan lama perendaman tidak berpengaruh nyata terhadap parameter pengamatan potensi tumbuh maksimum, daya berkecambah dan keserempakan tumbuh, tetapi berpengaruh nyata terhadap parameter pengamatan kecepatan tumbuh dan indeks vigor. Perlakuan suhu air sangat berpengaruh nyata terhadap potensi tumbuh maksimum, daya berkecambah, keserempakan tumbuh dan tidak berpengaruh nyata terhadap kecepatan tumbuh, indeks vigor dan tidak terjadi interaksi antara lama perendaman dan suhu air terhadap semua parameter pengamatan.

\section{Potensi Tumbuh Maksimum}

Dari Tabel rekapitulasi dapat dilihat bahwa perlakuan lama perendaman tidak berpengaruh nyata terhadap potensi tumbuh maksimum, tetapi perlakuan suhu air sangat berpengaruh nyata dan tidak terjadi interaksi antara keduanya. Rata-rata potensi tumbuh maksimum benih sengon akibat perlakuan lama perendaman dan suhu air dapat dilihat pada Tabel 3.

Tabel 3 menunjukkan bahwa potensi tumbuh maksimum benih sengon pada perlakuan lama perendaman memiliki kemampuan yang berbeda dalam meningkatkan potensi tumbuh maksimum, potensi tumbuh maksimum tertinggi di jumpai pada perlakuan lama perendaman 8 jam yaitu dengan nilai $56,33 \%$. Sedangkan potensi tumbuh maksimum terendah di jumpai pada perlakuan lama perendaman kontrol (tidak ada perendaman) yaitu dengan nilai $45,66 \%$.

Tabel 2. Rekapitulasi sidik ragam perlakuan lama perendaman dan suhu air serta interaksi keduanya.

\begin{tabular}{lccc}
\hline \multirow{2}{*}{ Pengamatan } & \multicolumn{3}{c}{ Perlakuan } \\
\cline { 2 - 4 } & $\mathrm{L}$ & $\mathrm{S}$ & $\mathrm{LxS}$ \\
\hline Potensi Tumbuh Maksimum & tn & $* *$ & tn \\
Daya Berkecambah & tn & $* *$ & tn \\
Keserempakan Tumbuh & tn & $*$ & tn \\
Kecepatan Tumbuh & $*$ & tn & tn \\
Indek Vigor & $*$ & tn & tn \\
\hline
\end{tabular}

Keterangan: $\mathrm{tn}=$ Tidak berbeda nyata; $*=$ Berbeda nyata; $* *=$ Sangat berbeda nyata; L= Lama perendaman; $S=$ Suhu air; $L x S=$ Interaksi lama perendaman dan suhu air.

Potensi tumbuh maksimum pada perlakuan suhu air juga memiliki kemampuan yang berbeda, potensi tumbuh maksimum tertinggi di jumpai pada perlakuan suhu air $60^{\circ} \mathrm{C}$ yaitu dengan nilai $65,77 \%$. Sedangkan potensi tumbuh maksimum terendah di jumpai pada perlakun suhu air kontrol (tidak ada perlakuan suhu air) yaitu dengan nilai $38,11 \%$. Hal ini diduga karena semakin panas suhu air maka semakin membuat kulit benih menjadi lunak dan semakin tinggi kemampuan benih untuk menyerap air, sehingga pertumbuhan/daya tumbuh benih makin tinggi. 
Tabel 3. Rata-rata potensi tumbuh maksimum benih sengon akibat perlakuan lama perendaman dan suhu air (\%).

\begin{tabular}{lc}
\hline $\begin{array}{c}\text { Lama Perendaman } \\
(\mathrm{L})\end{array}$ & $\begin{array}{c}\text { Potensi Tumbuh } \\
\text { Maksimum (PTM) }\end{array}$ \\
\hline Kontrol & $45.66 \mathrm{a}$ \\
$2 \mathrm{Jam}$ & $51.66 \mathrm{a}$ \\
$4 \mathrm{Jam}$ & $53.50 \mathrm{a}$ \\
$6 \mathrm{Jam}$ & $51.66 \mathrm{a}$ \\
$8 \mathrm{Jam}$ & $56.33 \mathrm{a}$ \\
$10 \mathrm{Jam}$ & $51.33 \mathrm{a}$ \\
\hline \multicolumn{1}{c}{ Suhu Air $(\mathrm{S})$} & Potensi Tumbuh \\
\hline Kontrol & $38.11 \mathrm{~b}$ \\
$40{ }^{\circ} \mathrm{C}$ & $42.66 \mathrm{~b}$ \\
$50^{\circ} \mathrm{C}$ & $60.22 \mathrm{a}$ \\
$60^{\circ} \mathrm{C}$ & $65.77 \mathrm{a}$ \\
\hline $\mathrm{Ke}$
\end{tabular}

Keterangan: Angka-angka yang diikuti oleh huruf yang sama pada kolom yang sama tidak berbeda nyata berdasarkan uji Duncan taraf 0,05\%.

Hal ini sesuai dengan pendapat Suharti (2007) benih yang direndam air dengan suhu yang semakin tinggi maka semakin baik perkecambahannya, air panas dapat menghilangkan sumbat kalazal pada mikropil sehingga lebih banyak menyerap air.

\section{Daya Berkecambah}

Dari Tabel rekapitulasi dapat dilihat bahwa perlakuan lama perendaman tidak berpengaruh nyata terhadap daya kecambah benih sengon tetapi perlakuan suhu berpengaruh sangat dan tidak terjadi-nya interaksi antara keduanya. Rata-rata daya berkecambah benih sengon akibat perlakuan lama perendaman dan suhu air dapat dilihat pada Tabel 4.

Tabel 4 menunjukkan bahwa daya berkecambah benih sengon tertinggi dijumpai pada perlakuan lama perendaman 8 jam dengan nilai $50,33 \%$. Sedangkan daya berkecambah terendah di jumpai pada perlakuan kontrol yaitu dengan nilai $34,66 \%$. Pada perlakuan suhu air daya berkecambah tertinggi di jumpai pada perlakuan suhu air $60^{\circ} \mathrm{C}$ yaitu dengan nilai $55,77 \%$. Sedangkan daya berkecambah terendah di jumpai pada perlakun suhu air $40^{\circ} \mathrm{C}$ yaitu dengan nilai $31,11 \%$.

Hasil penelitian Ani (2006) menyatakan hal yang sama, perlakuan perendaman benih dalam air panas terhadap daya kecambah tertinggi terdapat pada perlakuan suhu $60-70^{\circ} \mathrm{C}$, daya kecambahnya mencapai $75 \%$ dibandingkan dengan perlakuan kontrol atau tanpa perendaman.

\section{Keserempakan Tumbuh}

Dari Tabel rekapitulasi dapat dilihat bahwa perlakuan lama perendaman tidak berpengaruh nyata terhadap keserempakan tumbuh, tetapi perlakuan suhu air sangat berpengaruh nyata dan tidak terjadi interaksi antara keduanya. Rata-rata keserempakan tumbuh benih sengon akibat perlakuan lama perendaman dan suhu air dapat dilihat pada Tabel 5. Tabel 5 menunjukkan bahwa keserempakan tumbuh benih sengon tertinggi dijumpai pada perlakuan lama perendaman 8 jam dengan nilai nilai $42,00 \%$. Sedangkan keserempakan tumbuh terendah di jumpai pada perlakuan kontrol yaitu dengan nilai 20,66\%. Pada perlakuan suhu air keserempakan tumbuh tertinggi di jumpai pada perlakuan suhu air $60^{\circ} \mathrm{C}$ yaitu dengan nilai 36,44\% dan keserempakan tumbuh terendah di jumpai pada perlakun suhu air $40^{\circ} \mathrm{C}$ yaitu dengan nilai $22,66 \%$.

Tabel 4. Rata-rata daya berkecambah benih sengon akibat perlakuan lama perendaman dan suhu air $(\%)$.

\begin{tabular}{lc}
\hline Lama Perendaman (L) & Daya Berkecambah (DB) \\
\hline Kontrol & $34.66 \mathrm{a}$ \\
$2 \mathrm{Jam}$ & $41.00 \mathrm{a}$ \\
$4 \mathrm{Jam}$ & $44.33 \mathrm{a}$ \\
$6 \mathrm{Jam}$ & $43.66 \mathrm{a}$ \\
$8 \mathrm{Jam}$ & $50.33 \mathrm{a}$ \\
$10 \mathrm{Jam}$ & $43.00 \mathrm{a}$ \\
\hline Suhu Air $(\mathrm{S})$ & Daya Berkecambah (DB) \\
\hline Kontrol & $34.44 \mathrm{~b}$ \\
$40^{\circ} \mathrm{C}$ & $31.11 \mathrm{~b}$ \\
$50^{\circ} \mathrm{C}$ & $50.00 \mathrm{a}$ \\
$60^{\circ} \mathrm{C}$ & $55.77 \mathrm{a}$ \\
\hline
\end{tabular}

Keterangan: Angka-angka yang diikuti oleh huruf yang sama pada kolom yang sama tidak berbeda nyata berdasarkan uji Duncan taraf 0,05\%.

Terjadinya peningkatan keserempakan tumbuh diduga dengan adanya perendaman benih dalam air panas maka penyerapan air oleh benih (proses imbibisi) meningkat karena kulit benih menjadi lebih lunak. Setiadi et.al, 2005 juga menyatakan bahwa perlakuan perendaman benih dalam air dilakukan untuk merubah 
kondisi kulit benih yang keras, menghilangkan zat penghambat, melunakkan kulit benih dan mempercepat proses perkecambahan

\section{Kecepatan Tumbuh}

Dari Tabel rekapitulasi dapat dilihat bahwa perlakuan lama perendaman berpengaruh nyata terhadap kecepatan tumbuh benih dan perlakuan suhu air tidak berpengaruh nyata terhadap kecepatan tumbuh benih dan tidak terjadi interaksi antara keduanya. Rata-rata kecepatan tumbuh maksimum benih sengon akibat perlakuan lama perendaman dan suhu air dapat dilihat pada Tabel 6 .

Tabel 6 menunjukkan bahwa kecepatan tumbuh benih sengon tertinggi dijumpai pada perlakuan lama perendaman 8 jam dengan nilai nilai $20,46 \%$. Sedangkan kecepatan tumbuh terendah di jumpai pada perlakuan kontrol yaitu dengan nilai $7,63 \%$. Dari hasil penelitian di dapatkan bahwa kecepatan tumbuh terbaik terdapat pada perendaman $8 \mathrm{jam}$, hal ini diduga air yang masuk kedalam benih dengan perendaman 8 jam sudah mencukupi kebu-tuhan benih untuk proses mempercepat perkecambahannya secara maksimal. Sedangkan yang terendah pada perendaman kontrol yaitu tanpa peren-daman, hal ini di duga karena tanpa perendaman benih sukar untuk menyerap air karena tidak terjadinya proses imbibisi/pembengkakan biji.

Tabel 5. Rata-rata keserempakan tumbuh benih sengon akibat perlakuan lama perendaman dan suhu air (\%)

\begin{tabular}{lc}
\hline $\begin{array}{c}\text { Lama Perendaman } \\
(\mathrm{L})\end{array}$ & $\begin{array}{c}\text { Keserampakan Tumbuh } \\
\left(\mathrm{K}_{\mathrm{ST}}\right)\end{array}$ \\
\hline Kontrol & $20.66 \mathrm{~b}$ \\
$2 \mathrm{Jam}$ & $29.33 \mathrm{ab}$ \\
$4 \mathrm{Jam}$ & $33.33 \mathrm{ab}$ \\
$6 \mathrm{Jam}$ & $36.66 \mathrm{ab}$ \\
$8 \mathrm{Jam}$ & $42.00 \mathrm{a}$ \\
$10 \mathrm{Jam}$ & $29.66 \mathrm{ab}$ \\
\hline \multirow{2}{*}{ Suhu Air $(\mathrm{S})$} & Keserampakan Tumbuh \\
\hline Kontrol & $29.55 \mathrm{ab}$ \\
$40{ }^{\circ} \mathrm{C}$ & $22.66 \mathrm{~b}$ \\
$50^{\circ} \mathrm{C}$ & $39.11 \mathrm{a}$ \\
$60{ }^{\circ} \mathrm{C}$ & $36.44 \mathrm{a}$ \\
\hline
\end{tabular}

Keterangan: Angka-angka yang diikuti oleh huruf yang sama pada kolom yang sama berbeda nyata berdasarkan uji Duncan taraf 0,05\%.
Tabel 6. Rata- rata kecepatan tumbuh benih sengon akibat perlakuan lama perendaman dan suhu air $(\%)$

\begin{tabular}{lc}
\hline Lama Perendaman $(\mathrm{L})$ & $\begin{array}{c}\text { Kecepatan Tumbuh } \\
\left(\mathrm{K}_{\mathrm{CT}}\right)\end{array}$ \\
\hline Kontrol & $7.63 \mathrm{~b}$ \\
$2 \mathrm{Jam}$ & $9.68 \mathrm{~b}$ \\
$4 \mathrm{Jam}$ & $13.28 \mathrm{ab}$ \\
$6 \mathrm{Jam}$ & $13.79 \mathrm{ab}$ \\
$8 \mathrm{Jam}$ & $20.46 \mathrm{a}$ \\
$10 \mathrm{Jam}$ & $12.91 \mathrm{ab}$ \\
\hline \multicolumn{1}{c}{ Suhu Air $(\mathrm{S})$} & Kecepatan Tumbuh \\
\hline Kontrol & $\left(\mathrm{K}_{\mathrm{CT}}\right)$ \\
$40{ }^{\circ} \mathrm{C}$ & $11.16 \mathrm{ab}$ \\
$50^{\circ} \mathrm{C}$ & $8.62 \mathrm{~b}$ \\
$60^{\circ} \mathrm{C}$ & $17.46 \mathrm{a}$ \\
\hline
\end{tabular}

Keterangan: Angka-angka yang diikuti oleh huruf yang sama pada kolom yang sama berbeda nyata berdasarkan uji Duncan taraf 0,05\%

Benih sengon memiliki dormansi primer yaitu tiga lapis kulit dan dua lapis kulit terluarnya kutikula dan palisade kedap terhadap air dan udara yang me-lindungi benih dari desikasi dan sering kali meng-hambat perkecambahan benih sengon, sehingga pemecahan dormansi harus dilakukan. Salah satu cara yang dilakukan untuk memecahkan dormansi pada benih sengon adalah dengan cara merendam benih dalam air panas (Abimanyu, 2002).

Kecepatan tumbuh pada perlakuan suhu air juga memiliki kemampuan yang berbeda, kecepatan tumbuh tertinggi di jumpai pada perlakuan suhu air $60^{\circ} \mathrm{C}$ yaitu dengan nilai $17,46 \%$. Sedangkan kece-patan tumbuh terendah di jumpai pada perlakun suhu air $40^{\circ} \mathrm{C}$ yaitu dengan nilai $8,62 \%$.

Sumanto dan Sriwahyuni (1993) menambah-kan bahwa perlakuan awal pada benih memberikan pengaruh terhadap kecepatan tumbuh benih, karena air dan oksigen yang dibutuhkan untuk per-kecambahan dapat dengan mudah masuk kedalam benih. Benih dengan perlakuan perendaman dengan air panas mengalami peningkatan perkecambahan dibandingkan dengan perlakuan kontrol.

\section{Indeks Vigor}

Dari Tabel rekapitulasi dapat dilihat bahwa perlakuan lama perendaman berpengaruh nyata terhadapindeks vigor dan perlakuan suhu 
air tidak berpengaruh nyata terhadapindeks vigor dan tidak terjadi interaksi antara keduanya. Ratarata nilai indeks vigor benih sengon dengan perlakuan lama perendaman dan suhu air tertera pada Tabel 7.

Tabel 7. Rata-rata indeks vigor benih sengon akibat perlakuan lama perendaman dan suhu air (\%)

\begin{tabular}{lc}
\hline Lama Perendaman (L) & Indeks Vigor (IV) \\
\hline Kontrol & $3.33 \mathrm{~b}$ \\
$2 \mathrm{Jam}$ & $7.33 \mathrm{ab}$ \\
$4 \mathrm{Jam}$ & $10.00 \mathrm{ab}$ \\
$6 \mathrm{Jam}$ & $11.33 \mathrm{a}$ \\
$8 \mathrm{Jam}$ & $12.66 \mathrm{a}$ \\
$10 \mathrm{Jam}$ & $9.66 \mathrm{ab}$ \\
\hline Suhu Air (S) & Indeks Vigor (IV) \\
\hline Kontrol & $10.22 \mathrm{a}$ \\
$40^{\circ} \mathrm{C}$ & $6.44 \mathrm{a}$ \\
$50^{\circ} \mathrm{C}$ & $10.00 \mathrm{a}$ \\
$60^{\circ} \mathrm{C}$ & $9.55 \mathrm{a}$ \\
\hline
\end{tabular}

Keterangan: Angka-angka yang di ikuti oleh huruf yang sama pada kolom yang sama berbeda nyata berdasarkan uji Duncan taraf 0,05\%.

Tabel 7 menunjukkan bahwa indeks vigor tertinggi dijumpai pada perlakuan lama perendaman 8 jam dengan nilai $12,66 \%$. Sedangkan indeks vigor terendah di jumpai pada perlakuan kontrol yaitu dengan nilai 3,33\%. Hal ini diduga dengan lama perendaman 8 jam benih mendapatkan penyerapan air yang cukup maksimal untuk dapat berkecambah dengan baik. Selain itu dengan pencelupan dalam air panas juga mempercepat proses imbibisi (penye-rapan air) karena suhu memegang peranan yang sangat penting karena memberikan tekanan untuk masuknya air ke dalam biji dan air sudah dapat menembus kulit biji (Schmid, 2002).

Selanjutnya pengaruh perlakuan suhu air terhadap indeks vigor tertinggi di jumpai pada perlakuan kontrol tanpa perendaman yaitu dengan nilai $10,22 \%$. Sedangkan indeks vigor terendah di jumpai pada perlakun suhu air $40^{\circ} \mathrm{C}$ yaitu dengan nilai $6,44 \%$.

\section{Kesimpulan}

Lama perendaman tidak berpengaruh nyata terhadap perkecambahan benih sengon, namun tingkat pertumbuhan tertinggi terdapat pada perlakuan perendaman 8 jam pada semua parameter pengamatan. Suhu perendaman tidak berpengaruh nyata terhadap perkecambahan benih sengon, namun suhu terbaik di dapati pada perlakuan suhu $60^{\circ} \mathrm{C}$ kecuali pada parameter pengamatan indeks vigor.

\section{Daftar Pustaka}

Abimanyu D. 2002. Tanggap Semai Sengon (Paraseriathes falcataria (L.) Nielsen) Terhadap Inokulasi Ganda Cendawan Mikroriza Arbuskular dan Rizobium sp. (diakses 26 September 2013).

Ani N. 2006. Pengaruh Perendaman Benih Dalam Air Panas Terhadap Daya Kecambah Dan Pertumbuhan Bibit Lamtoro (Leucaena Leucochepala).

Komalasari A. 2011. Pecahan Dormansi. http: d//comalcomelayucomala.blogspot.com (diakses 7 Juli 2013).

Razi F. 2012. Mempelajari Kelayakan Usahatani Pembibitan Sengon. Skripsi. http://skripsi2013.blogspot.com/2012/11/mempelajarikelayakan-usahatani.html, (diakses 7 Juli 2013).

Schmid L. 2002. Pedoman Penanganan Benih Tanaman Hutan Tropis dan Sub Tropis (terjemahan) Dr. Mohammad Na'iem dkk. Bandung.

Setiadi. Susanto D, dan Maryati A, 2005. Perendaman Air Dingin Sebagai Perlakuan Perkecambahan Benih Jenis Araukaria. Jurnal Hutan Tanaman 2 (3) Oktober 2005, Bogor.

Sudomo A. 2011. Perkecambahan Benih Sengon (Falcataria moluccana (MIQ) Barneby \& J.W Grimes) Pada Empat Jenis Media.

Sumanto dan Sriwahyuni. 1993. Pengembangan Perlakuan Benih Terhadap Perkecambahan. Pusat Penelitian Dan Perkembangan Tanaman Industri.

Sutopo L. 2004. Teknologi Benih, ED. Revisi, Cet. 6. PT. Raja Grafindo, Jakarta.

Suharti. 2007. Pengaruh Perlakuan Awal Terhadap Viabilitas Benih Sengon Buto (Enterolobium cyclocarpum). Jurnal Hutan Tanaman 4 (1) Desember 2007, Bogor.

Zanzibar dan Herdiana N. 2006. Akurasi Metode Uji Cepat Dalam Menduga Viabilitas Benih Sengon. Jurnal Hutan Tanaman 3 (2) September 2006, Bogor. 